\title{
Orchidftgra
}

Vol. 1, No. 1, Bulan Februari Tahun 2021

DOI: http://dx.doi.org/10.35138/orchidagro.v1.i1.237

\section{Analisis Kekritisan Lahan Pada Fungsi Kawasan Konservasi Das Citarum Dengan Software Arcgis}

\author{
Dwi Hendra Kristianto ${ }^{1}$, Noertjahyani ${ }^{2}$, Endang Sufiadi ${ }^{2}$ \\ ${ }^{1}$ Mahasiswa Pascasarjana Agroteknologi, Universitas Winaya Mukti \\ ${ }^{2}$ Dosen Pascasarjana Agroteknologi, Universitas Winaya Mukti \\ Email: hendrakristianto78@gmail.com
}

(Received: 23-12-20; Published: 20-02-21)

\begin{abstract}
The research was conducted in a conservation area in the Citarum watershed area, one of the priority watersheds in Indonesia and is the largest and longest river in West Java. The analysis of land criticality in the Citarum watershed conservation area function using ArcGIS software was carried out in order to determine the criticality level of the land and what factors determine each level of land criticality in the conservation area in the Citarum watershed area. In determining the level of land criticality in conservation areas in the Citarum watershed, ArcGIS software is used which refers to the Decree of the Director General of Reforestation and Land Rehabilitation No. 41 / Kpts / V / 1998. Decree of the Director General of Land Rehabilitation and Social Forestry Number. SK.167 / V-SET / 2004, the variables include; land cover, slope, erosion sensitivity and management management. The results of the analysis of the location of the conservation area in the Citarum watershed, the variable of land cover is a factor that greatly affects the level of criticality of the land. The level of criticality of land was dominated by the Somewhat Critical class with an area of 8,999.58 Ha (57.71\%), followed by the Critical Potential class covering an area of 6,318.91 Ha (40.52\%), the Critical class covering an area of $249.43 \mathrm{Ha}(1.60 \%)$ and Very Critical class covering an area of $27.15 \mathrm{Ha}(0.17 \%)$ in a conservation area in the Citarum watershed with an area of 15,595.07 Ha. The factor that affects each level of criticality of land in the conservation area in the Citarum River Basin is the land cover variable which shows a positive (significant) relationship. The correlation value at the very critical level $(R=0.781)$ or $61.00 \%$, at the critical level $(R=0.302)$ or $9,12 \%$, at the somewhat critical level $(R=0.523)$ or equal to $27.35 \%$ and at critical potential level $(R=0.367)$ or equal to $13.47 \%$. Meanwhile, at the non-critical level, no data is available because there are no areas that fall into the non-critical category.
\end{abstract}

Keywords: ArcGIS software, critical land, conservation area.

\section{ABSTRAK}

Penelitian dilakukan pada Kawasan Konservasi di wilayah DAS Citarum salah satu DAS prioritas di Indonesia dan merupakan sungai terbesar dan terpanjang di Jawa Barat. Analisis Kekritisan Lahan pada Fungsi Kawasan Konservasi DAS Citarum dengan Software ArcGIS dilakukan dengan tujuan untuk mengetahui berapa luas tingkat kekritisan lahan dan faktor-faktor apa yang menentukan tiap tingkat kekritisan lahan pada kawasan koservasi di wilayah DAS Citarum. Dalam menentukan tingkat keritisan lahan pada kawasan konservasi di DAS Citarum, menggunakan Software ArcGIS yang merujuk kepada Surat Keputusan Direktur Jenderal Reboisasi dan Rehabilitasi Lahan Nomor. 41/Kpts/V/1998. Surat Keputusan Direktur Jenderal Rehabilitasi Lahan dan Perhutanan Sosial Nomor. SK.167/V-SET/2004, variabelnya meliputi; tutupan lahan, kemiringan lereng, kepekaan erosi dan manajemen pengelolaan. Hasil analisis lokasi kawasan konservasi di DAS Citarum variabel tutupan lahan merupakan faktor yang sangat mempengaruhi terhadap tingkat kekritisan lahan. Tingkat kekritisan 
lahan didominasi oleh kelas Agak Kritis dengan luas sebesar 8.999,58 Ha (57,71\%), diikuti oleh kelas Potensial Kritis seluas 6.318,91 Ha (40,52\%), kelas Kritis seluas 249,43 Ha (1,60\%) dan kelas Sangat Kritis seluas 27,15 Ha $(0,17 \%)$ pada kawasan konservasi di DAS Citarum dengan seluas 15.595,07 Ha. Faktor yang berpengaruh terhadap setiap tingkat kekritisan lahan pada kawasan koservasi di wilayah Daerah Aliran Sungai Citarum yaitu variabel tutupan lahan yang menunjukan hubungan positif (signifikan). Nilai korelasi pada tingkat sangat kritis $(\mathrm{R}=0,781)$ atau sebesar $61,00 \%$, pada tingkat kritis $(\mathrm{R}=0,302)$ atau sebesar $9,12 \%$, pada tingkat agak kritis $(\mathrm{R}=0,523)$ atau sebesar $27,35 \%$ dan pada tingkat potensial kritis $(\mathrm{R}=0,367)$ atau sebesar $13,47 \%$. Sedangkan pada tingkat tidak kritis, tidak tersedia data karena tidak terdapat areal yang masuk dalam kategori kelas tidak kritis.

Kata kunci: kawasan konservasi, lahan kritis, software ArcGIS.

\section{PENDAHULUAN}

Hutan merupakan sumber daya alam yang mempunyai fungsi produksi, ekologi dan sosial ekonomi. Kawasan hutan yang mempunyai fungsi pokok sebagai perlindungan system penyangga kehidupan untuk mengatur tata air, mencengah banjir, mengendalikan erosi, mencegah intrusi air laut, dan memelihara kesuburan tanah (Peraturan Pemerintan Repuplik Indonesia, 2010)

Sumberdaya alam berupa hutan, tanah dan air merupakan salah satu modal dasar pembangunan nasional yang harus dikelola dan dimanfaatkan sebaik-baiknya berdasarkan azas kelestarian, keserasian dan kemanfaatan, agar dapat memberikan manfaat ekonomi, ekologi dan sosial secara seimbang. Untuk mendukung hal tersebut, pembangunan bidang kehutanan perlu diarahkan pada pengelolaan sumber daya hutan secara lestari dan berkelanjutan, yang meliputi pengawetan fungsi ekologi, pembangunan ekonomi dan mampu memenuhi kebutuhan sosial masyarakat (Presiden Republik Indonesia, 1990).

Pemanfaatan sumberdaya hutan dewasa ini, di satu sisi telah memberikan manfaat sosial dan ekonomi yang cukup baik. Namun, di sisi lain manfaat ekologis sering kali terbaikan, akibatnya terjadi ketidak seimbangan ekosistem hutan yang berdampak buruk pada kerusakan lingkungan di wilayah Daerah Aliran Sungai (DAS).

Permasalahan pengelolaan DAS yang umum terjadi antara lain: 1) erosi tanah dan tanah longsor, serta terbentuknya lahan kritis, 2) terganggunya kuantitas, kualitas dan kontinyuitas sumber daya air, 3) penurunan produktivitas lahan pertanian, 4) degradasi sumber daya hutan, 5) berkurangnya luas hutan dan lahan pertanian, serta 6) penurunan tingkat kesesuaian lahan. Permasalahan tersebut secara umur terjadi di wilayah hulu, namun dampaknya juga akan dirasakan di wilayah hilirnya, seperti sedimentasi, banjir, pencemaran air, kekeringan sampai kemiskinan (Pratiwi and Salim, 2019).

Sumber-sumber penyebab kerusakan lingkungan DAS saat ini diantaranya pemanfaatan hutan yang tidak sesuai kaidahkaidah konservasi dan melampaui daya dukungnya, sehingga menyebabkan terjadinya lahan kritis. Lahan kritis merupakan lahan yang tidak produktif. Meskipun dikelola, produktivitas lahan kritis sangat rendah, bahkan dapat terjadi hasil produksi yang diterima jauh lebih sedikit daripada biaya produksinya.

Lahan kritis bersifat tandus, gundul, dan tidak dapat digunakan untuk usaha pertanian, karena tingkat kesuburannya sangat rendah. Disamping itu prilaku masyarakat yang belum mendukung konservasi seperti illegal logging dan penyerobotan lahan hutan akan menyebabkan deforestasi. Dalam upaya mengendalikan dan mencegah terjadinya kerusakan hutan konservasi yang merupakan bagian dari di wilayah DAS maka diperlukan adanya upaya-upaya rehabilitasi hutan rusak atau kritis, serta pengembangan fungsi DAS terus ditingkatkan (Abdulah, 2010). 
Beberapa permasalahan pokok yang dapat dijadikan sebagai titik tolak dalam upaya rehabilitasi lahan. Permasalahan pokok tersebut adalah tekanan penduduk terhadap lahan sangat tinggi, hal ini ditunjukkan oleh luas kepemilikan lahan yang rendah yaitu kurang dari satu hektar. Kondisi ini memicu terjadinya pemanfaatan lahan yang tidak sesuai dengan kemampuan lahan sehingga terjadi erosi, banjir dan tanah longsor di beberapa wilayah sub DAS. Selain itu, penerapan teknik konservasi tanah dan air yang belum tepat, rendahnya tingkat adopsi masyarakat terhadap ilmu dan teknologi, serta kurangnya pemahaman masyarakat tentang peranan hutan dalam konservasi tanah dan air (Pratiwi and Salim, 2019). Untuk mengatasi permasalahan tersebut perlu upaya yang serius baik melalui pendekatan fungsional atau pendekatana struktur berupa pencegahan alih fungsi lahan, reboisasi, penghijauan dan sebagainya (Mawardi, 2010).

Dari hasil review wilayah pengelolaan DAS tahun 2008 oleh Balai Pengelolaan DAS Citarum-Ciliwung, diketahui kawasan konservasi yang berada dalam wilayah pengelolaan DAS Citarum-Ciliwung memiliki luas 53.525,17 Ha (BBKSDA Jabar, 2011). Selanjutnya dari hasil review penyusunan lahan kritis tahun 2009 oleh BP DAS CitarumCiliwung dapat digolongkan dalam kelas kritis, yaitu Sangat Kritis seluas 1.196,34 Ha, Kritis seluas 3.619,57 Ha, Agak Kritis seluas 4.054,36 Ha, Potensial Kritis/Tidak Kritis seluas 44.654,90 Ha dan (BBKSDA Jabar, 2011).

Penentuan suatu areal kedalam lahan kritis mengacu kepada parameter penentu kekritisan lahan berdasarkan Surat Keputusan Direktur Jenderal Reboisasi dan Rehabilitasi Lahan Nomor. 41/Kpts/V/1998 tanggal 21 April 1998 yang telah dirubah melalui Surat Keputusan Direktur Jenderal Rehabilitasi Lahan dan Perhutanan Sosial Nomor. SK.167/V-SET/2004 meliputi ; kondisi tutupan lahan, kemiringan lereng, tingkat bahaya erosi dan singkapan batuan (outcrop), dan kondisi/manajemen pengelolaan (Direktorat Jenderal Bina Pengelolaan Daerah Aliran Sungai dan Perhutanan Sosial, 2013).

Memperhatikan kondisi beberapa area di dalam kawasan konservasi pada DAS Citarum yang termasuk dalam kategori sangat kritis dan kritis, maka peranan DAS di kawasan konservasi tersebut utamanya sebagai sistem pengatur tata air dan unsur produktivitas lahan dapat dikatakan kurang berfungsi lagi secara normal, akibatnya telah menyebabkan terganggunya keseimbangan ekosistem. Karena itu, pemulihan ekosistem dan peningkatan fungsi hutan kritis harus segera dilakukan. Guna merehabilitasi lahan kritis secara efektif dan efesien diperlukan informasi lengkap tentang lahan kritis dan penyebabpenyebab timbulnya lahan kritis tersebut. Pengumpulan dan penyajian data yang cepat dan akurat merupakan prosedur yang sangat penting dalam proses perencanaan mengenai lahan kritis, karena akan diperoleh data yang sesuai dengan keadaan lapangan yang terbaru. Untuk merencanakan penanganan lahan kritis dilakukan dengan mengoverlay data konsisi lapangan dalam bentuk peta, sehingga dapat diketaui tingkat kekritisan lahan masingmasing area yang disajikan dalam bentuk peta lahan kritis (Widyatmanti et al., 2018).

Dengan SIG akan dimudahkan dalam melihat fenomena kebumian dengan perspektif yang lebih baik. SIG mampu mengakomodasi penyimpanan, pemrosesan, dan penayangan data spasial digital bahkan integrasi data yang beragam, mulai dari citra satelit, foto udara, peta bahkan data statistik. Dengan tersedianya komputer dengan kecepatan dan kapasitas ruang penyimpanan besar seperti saat ini, SIG akan mampu memproses data dengan cepat dan akurat dan menampilkannya. SIG juga mengakomodasi dinamika data, pemutakhiran data yang akan menjadi lebih mudah (Wibowo et al., 2015).

Untuk mempermudah analisis dan penilaian data yang tersedia dapat digunakan perangkat Sistem Informasi Geografi (SIG). 
Pemanfaatan sistem ini bertitik tolak dari prinsip dasar bahwa penetapan lahan kritis berkaitan dengan data geografis. Dengan demikian, SIG dapat digunakan untuk mengklasifikasikan lahan kritis berdasarkan kriteria pada setiap kawasan, sehingga luas dan sebarannya dapat diketahui dengan cepat dan akurat. Analisis kekritisan lahan pada kawasan konservasi dengan software arcgis Daerah Aliran Sungai Citarum, perlu dilaksanakan.

Penelitian ini bertujuan untuk mengetahui luas tingkat kekritisan lahan pada kawasan konservasi di wilayah Daerah Aliran Sungai Citarum. Dan mengetahui faktorfaktor yang berpengaruh terhadap tingkat kekritisan lahan pada kawasan koservasi di wilayah Daerah Aliran Sungai Citarum.

\section{METODE PENILITIAN}

\section{Metode yang digunakan}

Penelitian dilaksanakan dengan metode deskriptif verifikatif serta analisis spasial dengan Sistem Informasi Geografis (SIG) dan observasi lapangan. Metode deskriptif analitis digunakan dalam analisis data penelitian yang selanjutnya dikomparasi dengan data lapangan untuk dilakukan analisis data spasial dengan menggunakan program ArcGIS untuk pengolahan peta-peta tematik. Hasil overlay peta tematik di uji regresi untuk menentukan mengetahui hubungan antara kelas kekritisan lahan dengan variabel penentunya sehingga dapat digunakan sebagai langkah rekomendasi pemulihan ekosistem yang akan dilakukan dalam suatu kawasan konservasi.

\section{Tempat dan Waktu Penelitian}

Penelitian ini dilaksanakan di kawasan konservasi wilayah DAS Citarum yang meliputi 14 fungsi kawasan konservasi dengan luas 15.595,07 ha, dengan hasil yang akan diperoleh berupa data dan informasi terkini mengenai kondisi lahan kritis yang telah dilaksanakan penyesuaian dengan data input terbaru. Waktu pelaksanaan penelitian pada bulan Juli sampai dengan September 2017.

\section{Bahan dan Alat}

Bahan dan data yang digunakan dalam penelitian ini meliputi : (1) Peta Penutupan Lahan tahun 2014 hasil analisis dari Citra Landsat, (2) Peta Kelerengan tahun 2014 hasil interpolasi DEM SRTM 30, (3) Peta Jenis Tanah tahun 2010, (4) Peta Curah Hujan tahun 2014, (5) Peta Solum tanah tahun 2010, (6) Peta Penggunaan Lahan tahun 2012, dan (7) Peta Kawasan Konservasi tahun 2015. Sedangkan alat-alat yang digunakan dalam penelitian ini meliputi : (1) Unit pengolah data citra, perangkat lunak untuk SIG menggunakan software ArcGIS 10, (2) GPS, (3) Alat gambar, (4) Buku catatan lapangan.

\section{Operasional Variabel}

Analisis dari beberapa parameter lahan kritis sebagai variabel untuk menghasilkan data spasial yang menunjukkan tingkat kekritisan lahan. Parameter penentu lahan kritis yaitu tutupan lahan, kelerengan, kepekaan erosi dan manajemen pengelolaan yang mengacu pada Peraturan Menteri Kehutanan Nomor. P.32/Menhut-II/2009 tentang Tata Cara Penyusunan Rencana Rehabilitasi Hutan dan Lahan Daerah Aliran Sungai.

Data spasial lahan kritis didapat dengan melakukan tumpang susun terhadap empat parameter tersebut. Masing-masing parameter harus memiliki sistem proyeksi yang sama untuk mempermudah proses analisis spasial dengan menggunakan software ArcGIS dalam menentukan lahan kritis. Sistem proyeksi koordinat data spasial yang digunakan adalah Univesal Tranverse Mecator (UTM) zone 48S Datum WGS 1984.

Penyusun data spasial lahan kritis mengacu kepada Surat Keputusan Direktur Jenderal RRL Nomor. 41/Kpts/V/1998 jo. Surat Keputusan Direktur Jenderal RLPS Nomor. SK.167/V-SET/2004. Detail Petunjuk Teknis Penyusunan Data Spasial 
Lahan Kritis dengan software GIS dijabarkan dengan Peraturan Direktur Jenderal BPDAS

PS Nomor. P.4/V-SET/2013 adalah sebagai berikut :

Tabel 1. Kriteria Lahan Kritis di Kawasan Hutan Lindung

\begin{tabular}{|c|c|c|c|c|c|}
\hline No. & Kriteria (Bobot) & Kelas & Besaran/ Diskripsi & Skor & Keterangan \\
\hline \multirow[t]{5}{*}{1.} & Tutupan Lahan & 1. Sangat Baik & $>80 \%$ & 5 & Dinilai \\
\hline & $(50)$ & 2. Baik & $61 \%-80 \%$ & 4 & berdasarkan \% \\
\hline & & 3. Sedang & $41 \%-60 \%$ & 3 & tutupan tajuk \\
\hline & & 4. Buruk & $21 \%-40 \%$ & 2 & pohon \\
\hline & & 5. Sangat Buruk & $<20 \%$ & 1 & \\
\hline \multirow[t]{5}{*}{2.} & Kelerengan (20) & 1. Datar & $<8 \%$ & 5 & \\
\hline & & 2. Landai & $8 \%-15 \%$ & 4 & \\
\hline & & 3. Agak Curam & $16 \%-25 \%$ & 3 & \\
\hline & & 4. Curam & $26 \%-40 \%$ & 2 & \\
\hline & & 5. Sangat Curam & $>40 \%$ & 1 & \\
\hline \multirow[t]{4}{*}{3.} & Kepekaan Erosi & 1. Ringan & 0 dan I & 5 & Hasil overlay \\
\hline & (20) & 2. Sedang & II & 4 & Curah Hujan, \\
\hline & & 3. Berat & III & 3 & Jenis Tanah dan \\
\hline & & 4. Sangat Berat & IV & 2 & Solum Tanah \\
\hline \multirow[t]{3}{*}{4.} & Manajemen & 1. Baik & Lengkap & 5 & - $\quad$ Tata batas \\
\hline & Pengelolaan (10) & 2. Sedang & Tidak Lengkap & 3 & kawasan \\
\hline & & 3. Buruk & Tidak Ada & 1 & $\begin{array}{l}\text { - Pengamanan } \\
\text { kawasan } \\
\text { - } \quad \text { penyuluhan }\end{array}$ \\
\hline
\end{tabular}

Sumber : (Direktorat Jenderal Bina Pengelolaan Daerah Aliran Sungai dan Perhutanan Sosial, 2013)

\section{Teknik Pengumpulan Data \\ Desk Study}

Pengumpulan data dilakukan dengan memperhatikan variabel penyusun lahan kritis, yaitu dengan menyiapkan indikator dan data sehingga proses digitasi dan analisis data spasial dapat dilakukan. Proses tahap awal pengumpulan data penutupan lahan yang bersumber dari interpretasi data citra ALOS tahun 2014, sedangkan untuk peta kelerengan menggunakan file DEM yang dianalisis berdasarkan ketinggian tempat dan diklasifikasi menjadi kelas lereng. Peta kepekaan erosi merupakan hasil overlay dan skoring dari peta curah hujan, peta jenis tanah dan peta solum tanah. Manajemen pengelolaan didasarkan pada peta kawasan konservasi dan hasil penilaian METT. Indikator dan Metode Verifikasi Penyusun Lahan Kritis.

\section{Sistem Informasi Geografis}

Sistem Informasi Geografis

(Geographic Information System/GIS) yang selanjutnya akan disebut SIG merupakan sistem informasi berbasis komputer yang digunakan untuk mengolah dan menyimpan data atau informasi geografis. Teknologi SIG ini dapat mengintegrasikan sistem operasi basisdata seperti query dengan berbagai keuntungan analisis dari data vektor dan data raster yang memiliki koordinat pada titik bumi. SIG memiliki kemampuan untuk menghubungkan berbagai data pada suatu titik tertentu di bumi, menggabungkannya, menganalisa dan akhirnya memetakan hasilnya (Wibowo et al., 2015).

\section{Tahap Lapangan}

Pengamatan lapangan groundcheck berdasarkan hasil analisis desk study data terutama hasil interpretasi dan analisis berupa penutupan lahan dan kelas lereng. Metoda pengamatan lapangan dilakukan secara sampling dengan metoda random sampling dengan tetap memperhatikan keragaman dan kesamaan unit lahan yang diteliti. Sample diambil sebanyak 20-30 titik koordinat. Data yang dikumpulkan di kegiatan groundcheck 
adalah koordinat, kondisi lapangan, dokumentasi, kelerengan dan tutupan lahan.

\section{Rancangan Analisis dan Uji Hipotesis}

Metode yang digunakan dalam analisis tabular adalah metode skoring dengan menggunakan alat bantu perangkat lunak ArcGIS. Setiap variabel penentu lahan kritis diberi skor tertentu yang telah ditetapkan. Analisis hasil overlay data spasial, dengan mengklasifikasi hasil skoring pada masingmasing data spasial yang kemudian ditentukan tingkat kekritisan lahannya.

Dari hasil data keempat penyusun variabel dimaksud dilakukan analisis data statistik untuk menguji secara empiris

\section{HASIL DAN PEMBAHASAN}

\section{Karakteristik Lokasi Penelitian}

Lokasi penelitian dilakukan pada lahan kritis yang berada pada kawasan konservasi yang masuk pada DAS Citarum, dalam upaya memberikan gambaran mengenai kondisi faktual kawasan konservasi yang berada pada wilayah DAS Citarum dan merupakan pengatur tata air untuk perlindungan daerah Tabel 2. Kawasan konservasi pada DAS Citarum bagaimana pengaruh masing-masing variabel dengan menggunakan regresi stepwise (Janie, 2012). Regresi stepwise adalah salah satu metode untuk mendapatkan model terbaik dari sebuah analisis regresi. Secara definisi adalah gabungan antara metode forward dan backward, variabel yang pertama kali masuk adalah variabel yang korelasinya tertinggi dan signifikan dengan variabel dependent, variabel yang masuk kedua adalah variabel yang korelasi parsialnya tertinggi dan masih significant, setelah variabel tertentu masuk ke dalam model maka variabel lain yang ada di dalam model dievaluasi, jika ada variabel yang tidak significant maka variabel tersebut dikeluarkan.

hilir di bawahnya. Sebaran lokasi penelitian terdapat 15 (lima belas) kawasan konservasi yang terdiri dari Kawasan Suaka Alam (KSA), Kawasan Pelestarian Alam (KPA) dan Taman Buru (TB) yang termasuk dalam wilayah DAS Citarum dengan perincian sebagai berikut :

\begin{tabular}{|c|c|c|c|}
\hline No. & Nama Kawasan & $\begin{array}{l}\text { Luas } \\
(\mathrm{Ha})\end{array}$ & $\%$ dari Total Luasan \\
\hline 1. & CA Cadas Malang & 19,70 & 0,13 \\
\hline 2. & CA Cigenteng Cipanji & 38,89 & 0,25 \\
\hline 3. & CA Gn. Tangkuban Parahu & 13,51 & 0,09 \\
\hline 4. & CA Gunung Burangrang & $2.737,36$ & 17,55 \\
\hline 5. & CA Gunung Tilu & $3.603,46$ & 23,11 \\
\hline 6. & CA Kamojang & $4.012,33$ & 25,73 \\
\hline 7. & CA Malabar & 29,72 & 0,19 \\
\hline 8. & CA Papandayan & 939,38 & 6,02 \\
\hline 9. & CA Telaga Warna & 362,32 & 2,32 \\
\hline 10. & CA Yunghun & 2,04 & 0,01 \\
\hline 11. & TB Masigit Kareumbi & $3.022,88$ & 19,38 \\
\hline 12. & TWA Cimanggu & 135,42 & 0,87 \\
\hline 13. & TWA Jember & 52,36 & 0,34 \\
\hline 14. & TWA Kamojang & 534,96 & 3,43 \\
\hline \multirow[t]{2}{*}{15.} & TWA Gn. Tangkuban Parahu & 90,73 & 0,58 \\
\hline & Jumlah & $\mathbf{1 5 . 5 9 5 , 0 7}$ & 100,00 \\
\hline
\end{tabular}

Berdasarkan hasil analisis data spasial, terdapat 4 kawasan konservasi yang memiliki areal luas dalam mempengaruhi tutupan lahan pada cathment area DAS Citarum yaitu kawasan Cagar Alam Kamojang, Cagar Alam Gunung Tilu, Taman Buru Masigit Kareumbi 
dan Cagar Alam Burangrang sebesar 85,77\% berbanding dengan luas kawasan konservasi yang berada pada DAS Citarum. Masingmasing fungsi kawasan konservasi tersebut, dilakukan analisis dan kajian spasial dengan menggunakan parameter lahan kritis. Hasil analisis dan penetapan lahan kritis pada kawasan konservasi di DAS Citarum dengan menggunakan software ArcGIS dengan hasil sebagai berikut.

\section{Lahan Kritis}

Hasil analisis luas lahan kritis pada kawasan konservasi dapat dilihat pada Tabel 4 berikut.

Tabel 3. Lahan Kritis Kawasan Konservasi pada lokasi penelitian

\begin{tabular}{|c|c|c|c|c|c|c|c|}
\hline \multirow[b]{2}{*}{ No. } & \multirow[b]{2}{*}{ Nama Kawasan } & \multicolumn{5}{|c|}{ Klasifikasi Tingkat Kekritisan Lahan (Ha) } & \multirow[b]{2}{*}{$\begin{array}{c}\text { Jumlah } \\
(\mathrm{Ha})\end{array}$} \\
\hline & & $\begin{array}{c}\text { Sangat } \\
\text { Kritis } \\
\text { (Nilai 120 } \\
-180 \text { ) }\end{array}$ & $\begin{array}{c}\text { Kritis } \\
\text { (Nilai } \\
181-270 \text { ) }\end{array}$ & $\begin{array}{c}\text { Agak } \\
\text { Kritis } \\
\text { (Nilai } \\
271-360)\end{array}$ & $\begin{array}{c}\text { Potensial } \\
\text { Kritis } \\
\text { (Nilai 361 } \\
-450 \text { ) }\end{array}$ & $\begin{array}{c}\text { Tidak } \\
\text { Kritis } \\
\text { (Nilai } \\
451-500)\end{array}$ & \\
\hline 1. & $\begin{array}{l}\text { CA Cadas } \\
\text { Malang }\end{array}$ & - & - & 0,24 & 19,46 & - & 19,70 \\
\hline 2. & $\begin{array}{l}\text { CA Cigenteng } \\
\text { Cipanji }\end{array}$ & - & 1,38 & 32,50 & 5,01 & - & 38,89 \\
\hline 3. & $\begin{array}{l}\text { CA Gn. T. } \\
\text { Parahu }\end{array}$ & - & - & 12,40 & 1,22 & - & 13,62 \\
\hline 4. & $\begin{array}{l}\text { CA Gn. } \\
\text { Burangrang }\end{array}$ & - & 15,98 & $2.604,72$ & 116,64 & - & $2.737,34$ \\
\hline 5. & CA Gunung Tilu & - & 19,27 & 837,60 & $2.746,57$ & - & $3.603,43$ \\
\hline 6. & CA Kamojang & 27,15 & 128,54 & $2.728,49$ & $1.128,13$ & - & $4.012,31$ \\
\hline 7. & CA Malabar & - & - & 26,80 & 2,92 & - & 29,72 \\
\hline 8. & CA Papandayan & - & - & 767,49 & 171,89 & - & 939,38 \\
\hline 9. & $\begin{array}{l}\text { CA Telaga } \\
\text { Warna }\end{array}$ & - & - & 274,15 & 88,17 & - & 362,32 \\
\hline 10. & $\begin{array}{l}\text { CA Yunghun } \\
\text { TB Masigit }\end{array}$ & - & 0,01 & 2,03 & - & - & 2,04 \\
\hline 11. & Kareumbi & - & 0,19 & $1.369,94$ & - & - & $3.022,86$ \\
\hline 12. & TWA Cimanggu & - & 83,71 & 51,70 & - & - & 135,42 \\
\hline 13. & TWA Jember & - & 0,34 & 52,02 & - & - & 52,36 \\
\hline 14. & $\begin{array}{l}\text { TWA Kamojang } \\
\text { TWA Gn. T. }\end{array}$ & - & - & 188,53 & 346,42 & - & 534,96 \\
\hline 15. & Parahu & - & - & 50,96 & 39,77 & - & 90,73 \\
\hline & Total & 27,15 & 249,43 & $8.999,58$ & $6.318,91$ & - & $\mathbf{1 5 . 5 9 5 , 0 7}$ \\
\hline
\end{tabular}

Kawasan konservasi seluas $15.595,70$ Ha yang terletak pada daerah hulu DAS Citarum, diketahui bawah didominasi oleh lahan dengan klasifikasi Agak Kritis seluas 8.999,58 Ha atau sekitar 57,71\%, Potensial Kritis seluas 6.318,91 Ha atau sekitar 40,52\%, Kritis seluas 249,43 Ha atau sekitar 1,60\% dan Sangat Kritis seluas $27,15 \mathrm{Ha}$ atau sekitar 0,17\%. Klasifikasi Agak Kritis dan Potensial Kritis merupakan areal yang sangat mendominasi pada lokasi penelitian dengan kontribusi sebesar $98,23 \%$ dari total luas kawasan konservasi di wilayah DAS Citarum.

Berdasarkan Tabel 3. diketahui bahwa lahan yang agak kritis menyebar di seluruh 15 kawasan konservasi pada DAS Citarum. Lahan dengan klasifikasi Sangat Kritis hanya terdapat pada Cagar Alam Kamojang dengan luasan yang relatif kecil seluas $27,5 \mathrm{Ha}$ atau sebesar $0,17 \%$ dari seluruh lokasi penelitian. Lahan dengan 
klasifikasi Kritis tersebat 8 kawasan dengan luasan terbesar pada CA Kamojang seluas 128,54 Ha diikuti oleh kawasan TWA Cimanggu seluas 83,71 Ha. Sedangkan 6 kawasan yang lain luasan klasifikasi krituisnya kurang dari 20 Ha dengan total klasifikasi kritis di kawasan konservasi pada cathment area DAS Citarum sebesar 249,43 Ha atau $1,60 \%$ dari seluruh luas areal penelitian.

Klasifikasi lahan Agak Kritis hampir mendominasi pada seluruh kawasan konservasi, terbesar pada 15 kawasan dengan total luas 8.999,58 $\mathrm{Ha}$ atau $57,71 \%$. Luasan terbesar berturut-turut pada CA Kamojang, CA Burangrang dan TB Masigit kareumbi dengan luas 2.728,49 Ha, 2.604,72 Ha dan 1.369,94 Ha. Sedangkan pada CA Cadas Malang hanya 0,24 Ha dari 19,70 Ha Luas total kawasan, hal ini menandakan bahwa pada kawasan dari 4 kriteria penentuan lahan kritis memiliki skoring yang sangat tinggi. Klasifikasi lahan Potensial Kritis mendominasi kedua setelah Agak kritis dengan luasan $6.318,91 \mathrm{Ha}$ atau $40,52 \%$, dengan luasan terbesar pada CA Gunung Tilu dan CA Kamojang dengan luas berturut-turut $2.746,57 \mathrm{Ha}$ dan $1.128,13 \mathrm{Ha}$.

Kawasan konservasi pada DAS Citarum tidak terdapat Klasifikasi lahan Tidak Kritis,

Sebaran klasifikasi lahan kritis di kawasan konservasi pada DAS Citarum dapat dilihat dengan grafik dan peta pada Gambar 1 dan 2 berikut. semua kawasan termasuk pada klasifikasi Sangat kritis, Kritis, Agak Kritis dan Potensial Kritis, hal ini dimungkinkan bahwa dengan penunjukan sebagai kawasan konservasi lahan tersebut karena memiliki kriteria kelerengan yang cukup terjal, memiliki jenis tanah yang peka terhadap erosi, curah hujan relatif tinggi dan memiliki solum tanah yang relatif dangkal. Berdasarkan hasil lapangan, lahan yang masuk klasifikasi sangat kritis dan kritis, memiliki penutupan lahan yang kurang bagus dengan kondisi tutupan pertanian lahan kering, semak belukar dan atau lahan terbuka. Hal ini diakibatkan karena masih adanya gangguan keamanan kawasan berupa, perambahan, kebakaran hutan maupun pencurian tegakan hutan. Manajemen pengelolaan kawasan berupa pengamanan terhadap gangguan keamanan kawasan sangat diperlukan dan juga upaya-upaya perbaikan tutupan lahan baik dengan perlakuan penanaman maupun suksesi alam sehingga dapat mencegah terjadinya erosi terhadap kawasan-kawasan dengan tutupan lahan yang kurang baik untuk menghindari turunnya grade klasifikasi lahan kritis dari potensial kritis dan agak kritis ke kritis dampai dengan sangat kritis.

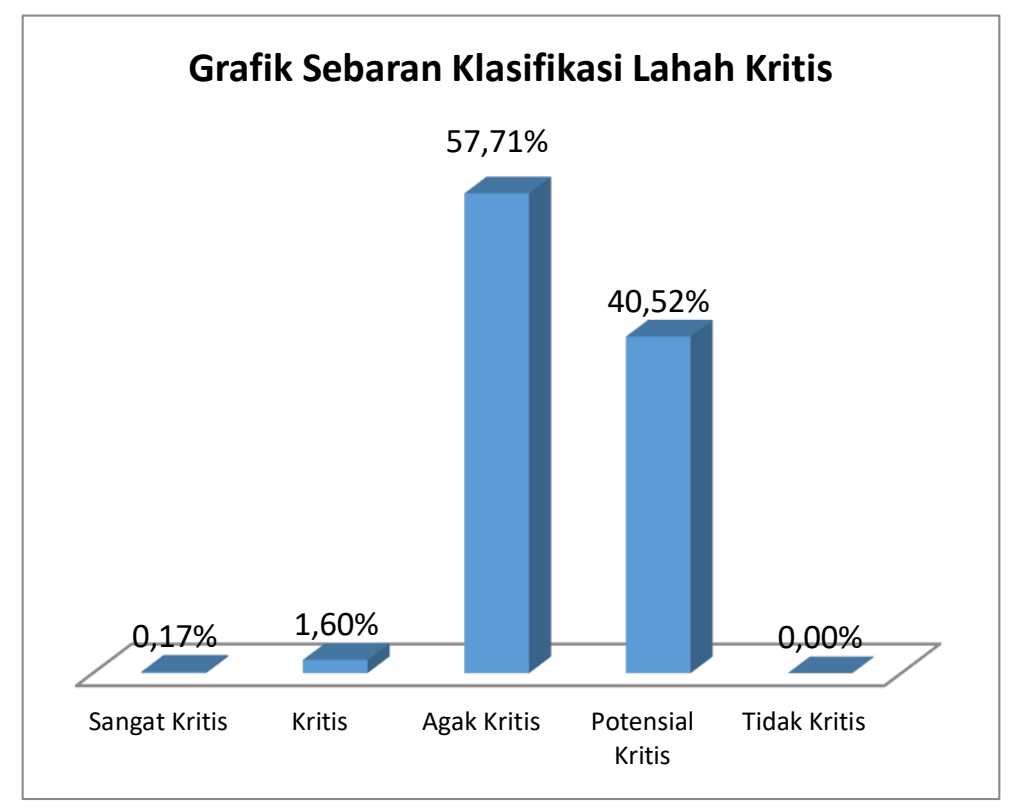

Gambar 1. Grafik sebaran lahan kritis pada lokasi penelitian 


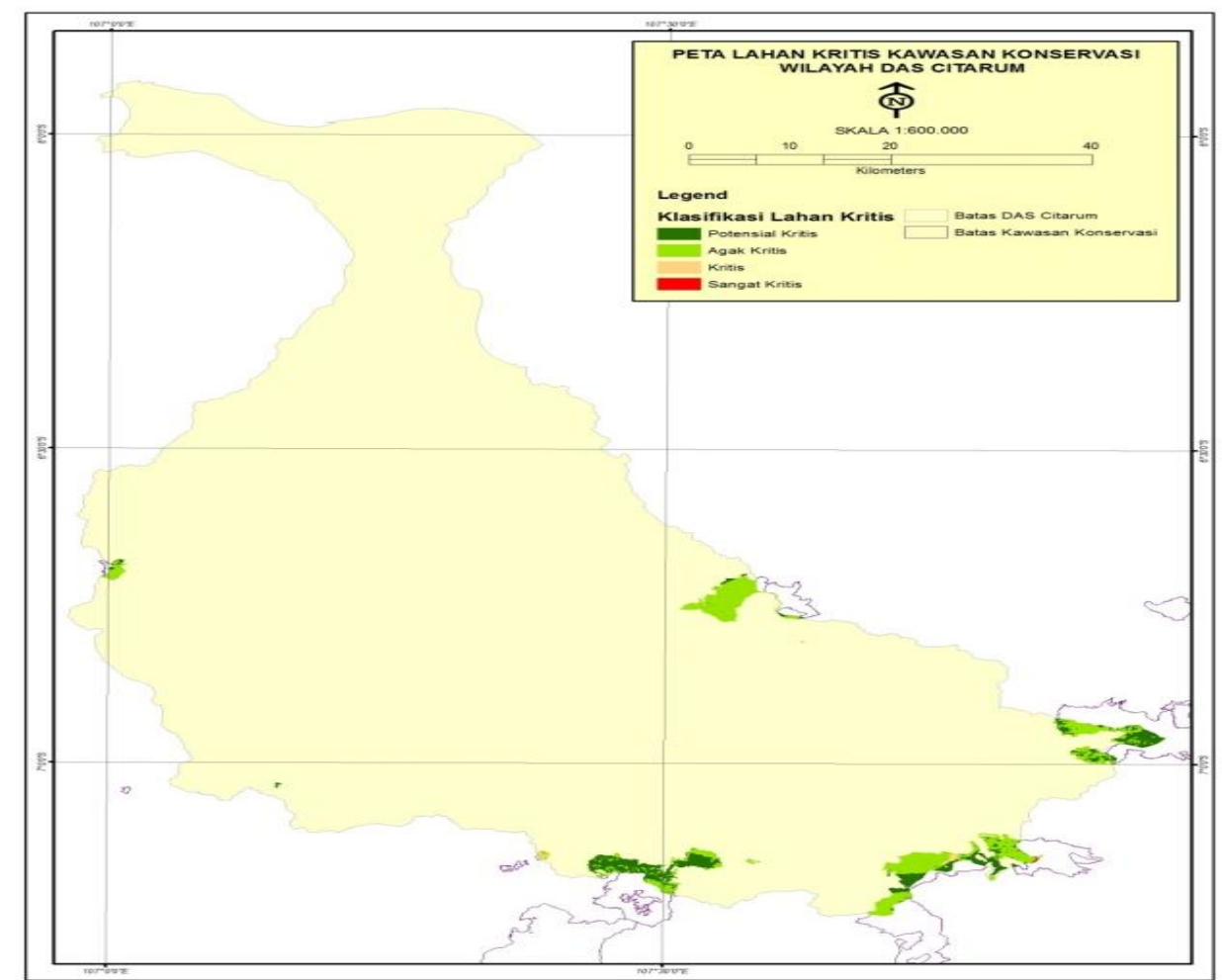

Gambar 2. Peta sebaran lahan kritis di kawasan konservasi pada lokasi penelitian

Hasil analisa data spasial dari beberapa variabel penyusun lahan kritis diketahui bahwa penutupan lahan merupakan faktor yang sangat berpengaruh dalam penentuan tingkat kekritisan lahan, ini ditunjukkan dengan besar bobot yang diberikan yaitu sebesar $50 \%$ pada arahan fungsi lindung yang berupa kawasan konservasi. Kondisi tutupan lahan diperoleh berdasarkan tutupan lahan, pada kawasan konservasi yang masih memiliki tutupan lahan yang Sangat Baik hanya sebesar $861,04 \mathrm{Ha}$ atau sebesar $5,52 \%$ yang merupakan Hutan Primer, sedangkan tutupan lahan berupa Hutan sekunder dan hutan tanaman seluas 13.577,16 Ha atau sebesar $87,06 \%$. Sedangkan lahan yang meliki tutupan lahan sedang sampai sangat buruk hanya seluas $1.156,87 \mathrm{Ha}$ atau sebesar 7,42\%. Melihat kondisi tutupan lahan di lokasi penelitian yang didominasi oleh kelas sangat baik dan baik dapat disimpulkan bahwa pada kawasn konservasi di wilayah DAS Citarum masih relatif baik yang didominasi oleh kelas keritisan lahan Agak Kritis dan Potensial Kritis, sehingga hanya
$1,77 \%$ atau seluas 276,58 yang masuk dalam kelas keritisan lahan Sangat Kristis dan Kritis. Upaya-upaya yang perlu dilakukan pada kawasan konservasi tersebut yaitu perlindungan dan pengawetan kawasan untyuk menjaga kawasan konservasi dari gangguan keamanan kawasan baik berupa pencurian vegetasi, kebakaran hutan maupun perambahan yang dapat mengakibatkan turunnya kelas tutupan lahan sehingga dapat menurunkan kelas kekritisan lahan dari Agak Kritis maupun Potensial Kritis menjadi lahan Kritis dan Sangat Kritis. Peraturan Pemerintah Nomor 28 Tahun 2011 menyebutkan bahwa upaya pengelolaan kawasan konservasi berupa kawasan pelestarian alam dan kawasan suaka alam meliputi kegiatan perencanaan, perlindungan, pengawetan dan pemanfaatan serta evaluasi kesesuaian fungsi kawasan.

Upaya lain yang harus dilakukan adalah pemulihan ekosistem baik secara alami melalui suksesi alam dengan cara menjamin kawasan dari gangguan dan tindakan masyarakat sekitar kawasan maupun dengan melakukan pengkayaan jenis terhadap 
kawasan dengan tutupan lahan yang sedang sampai dengan sangat buruk sehingga kawasan konservasi dapat berfungsi sebagai penyangga kehidupan dan pengatur tata air untuk daerah di bawahnya. Kegiatan pemulihan ekosistem dengan pengkayaan dilakukan dengan

\section{Analisis Korelasi}

Hasil analisis data statistik untuk mengetahui tingkat hubungan/korelasi dilakukan untuk mengetahui sejauh mana variabel tersebut dapat mempengaruhi menanam jenis endemik mengingat status kawasan merupakan Kawasan Suaka Alam (KSA) dan Kawasan Pelestarian Alam (KPA) serta Taman Buru yang memiliki aturan khusus dalam melakukan rehabilitasinya.

Tabel 1. Analisis Kolerasi pada Kawasan Konservasi di Wilayah DAS Citarum

\begin{tabular}{|c|c|c|c|c|c|}
\hline \multirow{2}{*}{$\begin{array}{l}\text { Variabel/Korelasi } \\
\text { terhadap } \\
\text { Kekritisan Lahan }\end{array}$} & \multicolumn{5}{|c|}{ Kelas Kekritisan Lahan } \\
\hline & Sangat Kritis & Kritis & Agak Kritis & $\begin{array}{l}\text { Potensial } \\
\text { Kritis }\end{array}$ & Tidak Kristis \\
\hline $\mathrm{TL}$ & 0,781 & 0,302 & 0,523 & 0,367 & Tidak ada data \\
\hline $\mathrm{L}$ & $-0,383$ & 0,235 & 0,195 & 0,312 & Tidak ada data \\
\hline $\mathrm{E}$ & $-0,552$ & 0,233 & 0,258 & 0,344 & Tidak ada data \\
\hline MP & 0,349 & 0,034 & 0,117 & 0,089 & Tidak ada data \\
\hline
\end{tabular}

Ket : KL $=$ Tingkat Kekritisan Lahan, TL $=$ Tutupan lahan, $\mathrm{L}=$ Kelerengan, E $=$ Kepekaan Erosi, MP = Manajemen Pengelolaan; Kelas kekritisan lahan tidak kritis tidak ada data

Berdasarkan data pada Tabel 23 dapat dilihat bahwa pada kawasan konservasi di wilayah DAS Citarum yang terdiri dari kelas keritisan lahan sangat kritis, kritis, agak kritis, potensial kritis dan tidak kritis. Hubungan antara kelas lahan sangat kritis, kritis, agak kritis, potensial kritis dengan variabel tutupan lahan mempunyai nilai masing-masing 0,781 ; 0,$302 ; 0,523$ dan 0,367 yang menunjukan hubungan positif (signifikan) dengan artian nilai tutupan lahan berpengaruh terhadap kelas kekritisan lahan. Semakin besar nilai tutupan lahan maka nilai nilai kekritisan lahan semakin besar pula, dengan kata lain bahwa semakin besar nilai variabel tersebut maka semakin tidak kritis suatu kawasan konservasi. Hubungan antara kelas kritis, agak kritis dan potensial kritis dengan variabel kelerengan, mempunyai nilai masing-masing 0,$235 ; 0,195$ dan 0,312 yang menunjukan hubungan positif (signifikan) dengan artian nilai kelerengan berpengaruh terhadap kelas kekritisan lahan. Sedangkan pada kelas sangat kritis menunjukan hubungan negatif dengan nilai 0,383 .

Hubungan antara kelas kritis, agak kritis dan potensial kritis dengan variabel kepekaan erosi, mempunyai nilai masingmasing 0,$233 ; 0,258$ dan 0,344 yang menunjukan hubungan positif (signifikan) dengan artian nilai kepekaan erosi berpengaruh terhadap kelas kekritisan lahan. Sedangkan pada kelas sangat kritis menunjukan hubungan negatif dengan nilai 0,552 . Hubungan antara kelas sangat kritis, kritis, agak kritis dan potensial kritis dengan variabel manajemen pengelolaan, mempunyai nilai masing-masing 0,$349 ; 0,034 ; 0,117$ dan 0,089 yang menunjukan hubungan positif (signifikan) dengan artian nilai kepekaan erosi berpengaruh terhadap kelas kekritisan lahan. Surat Keputusan Dirjen Reboisasi dan Rehabilitasi Lahan (1998) menyebutkan bahwa suatu kawasan lindung dinyatakan sangat kritis memiliki nilai skoring 120-180, kritis nilai skoring 181-270, agak kritis nilai 
skoring 271-360, potensial kritis 361-450 dan tidak kritis dengan nilai skoring 451-500.

Bentuk lereng bergantung pada proses erosi juga gerakan tanah dan pelapukan. Lereng merupakan parameter topografi yang terbagi dalam dua bagian yaitu kemiringan lereng dan beda tinggi relatif, dimana kedua bagian tersebut besar pengaruhnya terhadap penilaian suatu bahan kritis. Bila dimana suatu lahan yang lahan dapat merusak lahan secara fisik, kimia dan biologi, sehingga akan membahayakan hidrologi produksi pertanian dan pemukiman. Salah satunya dengan membuat Peta Kelas Lereng (Aqsar, 2009).

Secara detail dapat digambarkan bahwa dengan tingkat keyakinan 95\% tutupan lahan pada kelas sangat kritis memiliki nilai korelasi $\mathrm{R}=0,781$ dengan presentase data yang dapat dijelaskan dengan persamaan garis model tersebut yaitu $61,00 \%$ yang ditunjukan oleh nilai $\mathrm{R}^{2}=0,610$ memiliki kekuatan hubungan berkorelasi sangat kuat, pada kelas agak kritis memiliki nilai $\mathrm{R}=0,523$ dengan presentase data yang dapat dijelaskan dengan persamaan garis model tersebut yaitu $27,35 \%$ yang ditunjukan oleh nilai $\mathrm{R}^{2}=0,273$ memiliki kekuatan hubungan berkorelasi kuat, pada kelas potensial kritis memiliki nilai $\mathrm{R}=0,367$ dengan presentase data yang dapat dijelaskan dengan persamaan garis model tersebut yaitu $13,47 \%$ yang ditunjukan oleh nilai $R^{2}=0,134$ memiliki kekuatan hubungan berkorelasi cukup dan pada kelas kritis memiliki nilai $\mathrm{R}=0,302$ dengan presentase data yang dapat dijelaskan dengan persamaan garis model tersebut yaitu $9,12 \%$ yang ditunjukan oleh $\mathrm{R}^{2}=0,091$ memiliki kekuatan hubungan berkorelasi cukup. Pada setiap kelas kekritisan lahan variabel tutupan lahan berkorelasi positif dengan nilai korelasi cukup sampai dengan sangat kuat dalam memengaruhi kekritisan lahan. Primasari, Mulyadi, dan Ahmar (2019) menyebutkan bahwa untuk memudahkan melakukan interpretasi mengenai kekuatan hubungan antara dua variabel penulis memberikan kriteria sebagai berikut : 0 : Tidak ada korelasi, $0-0,25$ : Korelasi sangat lemah,
0,25 - 0,5: Korelasi cukup, 0,5 - 0,75: Korelasi kuat, 0,75 - 0,99: Korelasi sangat kuat dan 1: Korelasi sempurna.

Menurut undang-undang Nomor. 41 Tahun 1999 tentang Kehutanan, menyebutkan bahwa hutan konservasi adalah kawasan hutan dengan ciri khas tertentu, yang mempunyai fungsi pokok pengawetan keanekaragaman tumbuhan dan satwa serta ekosistemnya. Kawasan ditunjuk dan ditetapkan sebagai kawasan konservasi merupakan salah satu kawasan lindung yang mempunyai fungsi pokok sebagai perlindungan sistem penyangga kehidupan untuk mengatur tata air, mencegah banjir, mengendalikan erosi, mencegah intrusi air laut, dan memelihara kesuburan tanah, dalam pengelolaannya harus memenuhi kaidah-kaidah konservasi untuk menjamin keutuhan kawasan sehingga kawasan dapat berfungsi secara optimal dan lestari. Hal yang sangat mempengaruhi lahan kritis pada kawasan konservasi di wilayah DAS Citarum adalah tutupan lahan, sehingga dalam penanganan lahan kritis pada kawasan konservasi pemulihan tutupan lahan yang rusak sangat diperlukan untuk memperbaiki dan menurunkan kelas kekritisan lahan dari sangat kritis kekelas tidak kritis.

\section{KESIMPULAN DAN SARAN Kesimpulan}

Hasil analisis data spasial yang telah dilakukan dapat disimpulkan :

1. Tingkat kekritisan lahan didominasi oleh kelas Agak Kritis dengan luas sebesar 8.999,58 Ha $(57,71 \%)$, diikuti oleh kelas Potensial Kritis seluas 6.318,91 Ha (40,52\%), kelas Kritis seluas 249,43 Ha $(1,60 \%)$ dan kelas Sangat Kritis seluas 27,15 Ha $(0,17 \%)$ pada kawasan konservasi di DAS Citarum dengan seluas 15.595,07 Ha.

2. Faktor yang berpengaruh terhadap setiap tingkat kekritisan lahan pada kawasan koservasi di wilayah Daerah Aliran Sungai Citarum yaitu variabel tutupan lahan yang menunjukan hubungan positif (signifikan). 
Nilai korelasi pada tingkat sangat kritis $(\mathrm{R}=0,781)$ atau sebesar $61,00 \%$, pada tingkat kritis $(\mathrm{R}=0,302)$ atau sebesar $9,12 \%$, pada tingkat agak kritis $(\mathrm{R}=0,523)$ atau sebesar $27,35 \%$ dan pada tingkat potensial kritis $(\mathrm{R}=0,367)$ atau sebesar $13,47 \%$. Sedangkan pada tingkat tidak kritis, tidak tersedia data karena tidak terdapat areal yang masuk dalam kategori kelas tidak kritis.

\section{Saran}

Dari kesimpulan di atas dapat disarankan hal-hal sebagai berikut :

1. Penurunan tingkat kekritisan lahan dilakukan dengan cara pemulihan ekosistem antara lain (1) suksesi alam untuk lahan yang meiliki kelas Potensial Kritis, (2) restorasi atau pengkayaan jenis untuk lahan yang memiliki kelas Agak Kritis, dan (3) rehabilitasi untuk lahan yang memiliki kelas Kritis dan Sangat Kristis

2. Penanganan lahan kritis dilakukan secara terencana, sinergi, dan berkesinambungan antar pemangku kepentingan serta dilakukan secara partisipatif, sehingga masyarakat sekitar kawasan merasa memiliki dan menjaga keutuhan kawasan sebagai fungsi penyangga kehidupan dan tata air daerah dibawahnya.

3. Perlu dilakukan penelitian lanjutan untuk mengetahui secara detail seberapa besar nilai Tingkat Bahaya Erosi (TBE) pada kawasan konservasi di wilayah DAS Citarum, terutama pada kelas Sangat Kritis, Kritis dan Agak Kristis, sehingga dapat dijadikan masukan kepada pihak pengelola kawasan konservasi untuk pengambilan kebijakan dalam manajemen pengelolaan yang baik.

\section{DAFTAR PUSTAKA}
Abdulah, L. 2010. Lahan Dan Skenario Perdagangan Karbon. https://www.academia.edu/download/537 49961/tesis.pdf.

Aqsar, Z. El. 2009. Hubungan Ketinggian Dan
Kelerengan Dengan Tingkat Kerapatan Vegetasi Menggunakan Sistem Informasi Geografis Di Taman Nasional Gunung Leuser.

http://repository.usu.ac.id/bitstream/1234 56789/7648/1/09E02651.pdf.

Direktorat Jenderal Bina Pengelolaan Daerah Aliran Sungai dan Perhutanan Sosial. 2013. Peraturan Direktur Jenderal Bina Pengelolaan Daerah Aliran Sungai Dan Perhutanan Sosial Nomor: P.4/VSET/2013 Tentang Petunjuk Teknis Penyusunan Data Spasial Lahan Kritis. Kementeri. Lingkung. Hidup Dan Kehutan.: 1-23. http://www.sipdasmahakamberau.com/storages/file/cytsDT yuOGBExBTS.Pdf.

Janie, D.N.A. 2012. Statistik Deskriptif \& Regresi Linier Berganda Dengan SPSS. Semarang University Press, Semarang.

Mawardi, I. 2010. Kerusakan daerah aliran sungai dan penurunan daya dukung sumberdaya air di pulau jawa serta upaya penanganannya. J. Hidrosfir Indones. 5(2): 1-11. http://epaper.bppt.go.id/index.php/JHI/art icle/view/670.

Pratiwi, and A.G. Salim. 2019. Arahan Prioritas Rehabilitasi Lahan Kritis Di Sub DAS Cisangkuy, DAS Citarum. PT Penerbit IPB Press, Kota BogorIndonesia.

Primasari, A., J. Mulyadi, and N. Ahmar. 2019. Pengaruh Independensi, Audit Tenure, Beban Kerja, dan Tekanan Waktu terhadap Kemampuan Auditor dalam Mendeteksi Kecurangan dengan Variabel Moderasi Pemahaman Kondisi Entitas dan Supervisi. J. Inov. Manaj. Ekon. Dan Akunt. 1(1): 23-30. http://journal.univpancasila.ac.id/index.p $\mathrm{hp} / \mathrm{jimea} /$ article/download/880/561/.

Presidem Republik Indonesia. 1990. Undang Undang No . 5 Tahun 1990 Tentang: Konservasi Sumberdaya Alam Hayati. Jakarta.

Peraturan Pemerintah Republik Indonesia. 2010. Tata Cara Perubahan Peruntukan dan Fungsu Kawasan hutan. : 10. https://jdih.setkab.go.id/PUUdoc/16880/ PP0102010.htm.

Wibowo, K.M., I. Kanedi, and J. Jumadi. 2015. Sistem Informasi Geografis (SIG) Menentukan Lokasi Pertambangan Batu 
Bara di Provinsi Bengkulu Berbasis Website. J. Media Infotama 11(1): 5160.https://jurnal.unived.ac.id/index.php/j $\mathrm{mi} /$ article/view/252/231.

Widyatmanti, W., S.H. Murti, and P.D. Syam. 2018. Pemetaan Lahan Kritis Untuk Analisis Kesesuaian Pemanfaatan Lahan di Kabupaten Kulon Progo. J. Pengabdi. dan Pengemb. Masy. 1(1): 25-36. doi: 10.22146/jp2m.41024. 